\title{
Pendampingan Perilaku Hidup Bersih dan Sehat Berbasis Gereja di Sekolah Minggu Jemaat Gereja Protestan Maluku (GPM) Tihulale Kabupaten Seram Bagian Barat
}

\author{
Resa Dandirwalu, Desviana Maspaitella, Nining Gan, Yonaria Pattiapon, Vonda \\ Leasa, Pingkan P. Alfons, Jems Porumau, Eveline L. Kastanja, Dennyela P. \\ Siwabessy, Koce Tuatanasy, Melina Letelay, Rezky B. Tahalea, Yusuf R. Serpiela, \\ Marsel Mangar \\ Universitas Kristen Indonesia Maluku (UKIM) Ambon \\ E-mail: resadandirwalu@ukim.ac.id
}

Article History:

Received: 2020-03-11

Revised: 2020-01-17

Accepted: 2020-05-31
Keywords: Clean and Healthy Lifestyle, Sunday School Children, the GPM Tihulale Church

\begin{abstract}
Clean and healthy lifestyle is essential for all people especially children. Based on preliminary study, Sunday School Children of the GPM Tihulale Church had less adequate knowledge and skills regarding the habits of clean and healthy lifestyle. Therefore, this community service was carried out to improve clean and healthy attitudes as well as behaviors of Sunday School Children of the GPM Tihulale Church. The program was conducted through counselling and training and covered five stages: interviewing and analyzing the partners' needs, educating about clean and healthy behavior, giving health education and training on clean and healthy behavior, distributing free toothbrushes and toothpastes, and conducting evaluation and follow-up activities. The results obtained were an increase in children's knowledge and skills about clean and healthy lifestyle during their time in the Sunday School Service and daily lives.
\end{abstract}

\section{Pendahuluan}

Jemaat GPM Tihulale secara administrasi berada di Klasis GPM Kairatu, dengan luas wilayah 75,96 Km2, dengan jarak dari Ibu Kota Kecamatan $24 \mathrm{Km}$. Berdasarkan geografi, maka Jemaat GPM Tihulale terletak sebagai berikut: Sebelah Utara berbatasan dengan Hutan Negeri Huku dan Hunitetu; Sebelah Selatan berbatasan dengan Selat Seram; Sebelah Timur berbatasan dengan Jemaat GPM Rumahkay (Amakele) di air Siaputi; Sebelah Barat berbatasan dengan Jemaat GPM Kamariang (Amalohi) di air Eri. Jemaat GPM Tihulale terdiri dari 10 Sektor Pelayanan, dan 10 Unit Pelayanan, dengan jumlah anggota jemaat sebanyak 1.741 jiwa (perempuan: 877 jiwa dan laki-laki: 864 jiwa). ${ }^{1}$ Jarak antara Jemaat GPM Tihulale dengan Kota Ambon adalah 41,9 Km. Untuk sampai ke Jemaat tersebut, biasanya menggunakan kendaraan beroda dua atau beroda empat dari Kota Ambon menuju ke Dermaga yang berlokasi di Negeri Liang, dengan

${ }^{1}$ Jemaat GPM Tihulale (tidak dipublikasikan). Renstra Jemaat GPM Tihulale Tahun 2015-2020. 
waktu tempuh 30 menit, dilanjutkan dengan angkutan laut berupa Kapal Ferry menuju ke Dermaga yang berlokasi di Negeri Waipirit dengan waktu tempuh satu setengah jam, dan menggunakan angkutan darat berupa roda dua atau roda empat selama 15 menit.

Jemaat GPM Tihulale memiliki satu (1) Puskesmas Pembantu (Pustu), dengan satu (1) orang tenaga Bidan Honorer, dan beroperasi dari jam 08.00-12.00 WIT; selain itu peralatan medis dan obat-obatan belum tersedia secara memadai, sehingga anggota jemaat cenderung berobat ke Puskesmas yang letaknya di Kairatu; apabila anggota jemaat yang sakit, mereka cenderung mempergunakan obat-obatan tradisional yang diperoleh dari alam.

Berdasarkan hasil wawancara dengan Ibu Bidan dan Ibu Ketua Majelis Jemaat, tampak bahwa sebagian besar anggota jemaat mengalami sakit Diare, ISPA, Hipertensi, Flu, dan Batuk. Penyakit tersebut disebabkan oleh beberapa kebiasaaan yang menggambarkan perilaku hidup yang tidak sehat, seperti: jarang membersihkan tubuh (mandi), jarang menyikat gigi sesudah makan, jarang mencuci tangan sebelum makan, cenderung membuang sampah di sekitar lokasi tempat tinggal dan pantai, jarang memakai sandal saat keluar rumah atau ke kebun, jarang membawa bayi untuk ditimbang, dan cenderung mengkonsumsikan mie instan, sehingga realitas inilah yang membuat Tim memilih Jemaat GPM Tihulale sebagai Mitra untuk Pengabdian kepada Masyarakat.

Hasil penelitian dari Organisasi Kesehatan Dunia, menunjukan bahwa 100.000 anak Indonesia meninggal dunia akibat penyakit diare yang diderita, dan berdasarkan data dari Departemen Kesehatan RI, terdapat 300 orang yang terjangkit penyakit diare. ${ }^{2}$ Hal tersebut membuat Menteri Kesehatan Republik Indonesia mengeluarkan Peraturan Nomor: 226/MENKES/PER/XI/2011, tentang Perilaku Hidup Bersih dan Sehat di Seluruh Indonesia, yang dimulai dari tahap pengkajian, perencanaan, pelaksanaan, pemantauan dan penilaian. ${ }^{3}$ Pemerintah terus berusaha supaya masyarakat dapat menekankan aspek Hidup Sehat dan Bersih dalam seluruh aktivitas sehari-hari mereka, sehingga masyarakat Indonesia boleh memiliki hidup yang sehat.

Hidup sehat menurut Organisasi Kesehatan Dunia, mendefinisikan sehat sebagai keadaan sempurna secara fisik, mental dan sosial, maka lingkungan internal dan eksternal harus diperhatikan secara menyeluruh oleh setiap individu, ${ }^{4}$ senada dengan

2 Qurrotul Aeni, Fiera Beniarti, and Bambang Edy Warsito, "Pengaruh Pendidikan Kesehatan Dengan Metode Pemutaran Video Tentang PHBS Cuci Tangan Terhadap Pengetahuan Dan Sikap," Jurnal $\begin{array}{lllll}\text { Keperawatan } & 7, & 2 & \text { (2015): } & 1-5 \text {, }\end{array}$ http://journal.stikeskendal.ac.id/index.php/Keperawatan/article/view/18.

3 Fatwa Tentama, "Penerapan Perilaku Hidup Bersih Dan Sehat (Phbs) Demi Kesejahteraan Masyarakat Kecamatan Tuntang Kabupaten Semarang Jawa Tengah," Jurnal Pemberdayaan: Publikasi Hasil Pengabdian Kepada Masyarakat 1, no. 1 (2018): 13.

${ }^{4}$ Chandra, Akhmad Fauzan, and M Febriza Aquarista, "Hubungan Antara Pengetahuan Dan Sikap Dengan Perilaku Hidup Bersih Dan Sehat (Phbs) Pada Siswa Sekolah Dasar (Sd) Di Kecamatan Cerbon Tahun 2016," Jurnal Kesmas (Kesehatan Masyarakat) Khatulistiwa 4, no. 3 (2017): 201. 
Zaraz Obella Nur Adliyani, bahwa Sehat ialah keadaan sejahtera dari badan, jiwa, dan sosial yang memungkinkan setiap orang hidup produktif secara sosial dan ekonomis, ${ }^{5}$ hal inilah yang disebutkan oleh Endang Susanti dan Nur Kholisoh sebagai perilaku kesehatan, karena menekankan pada aktivitas yang dilakukan oleh setiap individu terkait dengan pemeliharaan dan peningkatan kesehatan, ${ }^{6}$ maka terciptalah tubuh yang sehat sehingga dapat melaksanakan seluruh aktivitas yang dilakukan. ${ }^{7}$ Dengan kata lain hidup menjadi baik sangat berhubungan erat dengan kesehatan. ${ }^{8}$

Berdasarkan hasil wawancara dengan Jemaat GPM Tihulale (Jemaat Mitra), maka disepakati bersama bahwa masalah utama mitra adalah Pembudayaan Perilaku Hidup Bersih dan Sehat kepada Anak-Anak Sekolah Minggu, karena selama ini mereka belum memiliki pengetahuan dan ketrampilan yang memadai tentang Pembudayaan Perilaku Hidup Bersih dan Sehat, dengan tujuannya adalah terciptanya peningkatan Sikap dan Perilaku Hidup Bersih dan Sehat di Anak-Anak Sekolah Minggu Jemaat GPM Tihulale. Menurut penelitian dari Gracia, dkk, bahwa Perilaku Hidup Bersih dan Sehat sangat berpengaruh pada kesehatan individu, sehingga pengetahuan menjadi salah satu faktor pembentukan perilaku hidup bersih dan sehat, sehingga mempengaruhi status kesehatan setiap individu. ${ }^{9}$ Karena itu, menurut Husni Abdul Gani, dkk, Perilaku Hidup Bersih dan Sehat (PHBS) harus dilaksanakan secara sistematis dan terkoordinir, sebab Program Perilaku Hidup Bersih dan Sehat (PHBS) merupakan bentuk perwujudan untuk memberikan pengalaman belajar atau menciptakan suatu kondisi yang kondusif bagi perorangan, keluarga, kelompok dan masyarakat untuk meningkatkan pengetahuan, sikap dan perilaku agar dapat menerapkan cara-cara hidup sehat dalam rangka menjaga, memelihara, dan meningkatkan kesehatan. ${ }^{10}$ Selanjutnya, realitas sebagai kenyataan-kenyataan sosial budaya di sekitar lingkungan masyarakat tertentu akibat dari pola-pola hubungan yang terjadi dalam masyarakat. Pola-pola hubungan tersebut dapat mencapai kestabilan tetapi dapat juga menimbulkan masalah, sehingga perilaku manusia dapat dipahami sebagai suatu aktifitas manusia dalam keseharian

5 Zaraz Obella and Nur Adliyani, "Pengaruh Perilaku Individu Terhadap Hidup Sehat The Effect of Human Behavior for Healthy Life," Majority 4, no. 7 (2015): 109-114.

${ }^{6}$ Endang Susanti and Nur Kholisoh, "Konstruksi Makna Kualitas Hidup Sehat (Studi Fenomenologi Pada Anggota Komunitas Herbalife Klub Sehat Ersanddi Jakarta)," LUGAS Jurnal Komunikasi 2, no. 1 (2018): 1-12.

${ }^{7}$ Halida Muniatin, Busri, "Pengenalan Pola Hidup Sehat Melalui Media Langsung Pada Anak Usia 4-5 Tahun RA AL-Hidayah," Journal of Chemical Information and Modeling 53, no. 9 (2013): 1689-1699.

${ }^{8}$ Siska Armawati Sufa, Nevrettia Christantyawati, and Raden Ayu Erni Jusnita, "Tren Gaya Hidup Sehat Dan Saluran Komunikasi Pelaku Pola Makan Food Combining," Jurnal Komunikasi Profesional 1, no. 2 (2017): 105-120.

${ }_{9}^{9}$ Bellytra Talarima Gracia V. Souisa, Ivy V. Lawalata, Samuel Titaley, "Peningkatan Perilaku Hidup Bersih Dan Sehat (PHBS) Pada Pendidik Dan Peserta Didik Di Kecamatan Leihitu Barat Kabupaten Maluku Tengah," Pengabdian Kepada Masyarakat 24, no. 3 (2018): 747-754.

${ }^{10}$ Husni Abdul Gani et al., "Perilaku Hidup Bersih Dan Sehat (PHBS) Pada Tatanan Rumah Tangga Masyarakat Using (Studi Kualitatif Di Desa Kemiren, Kecamatan Glagah, Kabupaten Banyuwangi) A Qualitative Study in Kemiren Village, Glagah Sub District, Banyuwangi Regency," Jurnal IKESMA 11, no. 1 (2015): 26-35. 
yang dipengaruhi oleh lingkungan dan biologis.

Berdasarkan permasalahan tersebut di atas, maka pendampingan perilaku hidup bersih dan sehat menjadi solusi dalam proses pengabdian kepada masyarakat di Jemaat GPM Tihulale, khususnya bagi anak-anak Sekolah Minggu. Pendampingan ini bertujuan agar anak-anak Sekolah Minggu, yang berjumlah 317 anak, di antaranya 184 anak memiliki pengetahuan dan ketrampilan yang memadai dan berdaya untuk menolong diri mereka sendiri dalam membudayakan Perilaku Hidup Bersih dan Sehat.

\section{Metode}

Subjek dampingan kegiatan Pengabdian kepada Masyarakat adalah Jemaat GPM Tihulale, khususnya kepada anak-anak Sekolah Minggu, dan berlokasi di Jemaat GPM Tihulale, yang berlangsung dari tanggal 7 Februari hingga tanggal 8 Maret 2020, dan dilakukan dalam 5 tahap, sebagaimana digambarkan pada table 1 di bawah ini.

Tabel 1. Tahap-Tahap Pengabdian Kepada Masyarakat

\begin{tabular}{l} 
Tahap dan Tujuan \\
\hline Tahap I \\
Wawancara dan Analisis \\
Kebutuhan Mitra \\
Tujuannya: \\
Menggali informasi dalam \\
rangka mendapatkan solusi \\
permasalahan yang efektif \\
dengan proses penyelesaian \\
masalah yang efisien.
\end{tabular}

Kegiatan dan Partisipasi Mitra

Tahap ini, dilakukan beberapa kegiatan, yaitu:

1. Wawancara dengan mitra, yaitu Ibu Pendeta, untuk menggali informasi terkait masalah mendesak yang sedang dihadapi dan membutuhkan penyelesaian. Hasil wawancara memperlihatkan bahwa permasalahan utama sebagaimana yang dijelaskan pada bagian Permasalahan Mitra. Wawancara ini berlangsung di Jemaat GPM Tihulale.

2. Wawancara dengan Bidan. Wawancara ini bertujuan untuk menghimpun informasi terkait masalah-masalah kesehatan yang dialami Jemaat Mitra. Kegiatan ini berlangsung di Pustu yang berada di Jemaat GPM Tihulale.

Partisipasi Mitra:

a. Mitra memberikan informasi tentang kesulitan yang selama ini dihadapi.

b. Mitra memberikan dokumen atau informasi yang dibutuhkan.

Tahap II

Pembudayaan Perilaku Hidup

Bersih dan Sehat.

Tujuannya:

1. Mengubah pola berpikir/pandang dan
Kegiatan yang dilakukan pada tahap ini adalah:

a. Melakukan evaluasi terhadap Perilaku Hidup Bersih dan Sehat yang selama ini dilakukan dalam kehidupan sehari-hari

b. Membudayakan Perilaku Hidup Bersih dan Sehat melalui pemberian contoh dan menanamkan pembiasaan sikap Praktek Hidup Bersih dan Sehat 
bertingkah laku terkait hidup bersih dan sehat.

2. Membudayakan Perilaku Hidup Bersih dan Sehat dalam seluruh aktivitas keseharian.

\section{Tahap III}

Penyuluhan dan Pelatihan

Kesehatan tentang Perilaku

Hidup Bersih dan Sehat.

Tujuannya:

Memiliki pemahaman yang baik dan benar tentang berbagai dampak negatif yang ditimbulkan dari aktivitas keseharian yang salah tentang Perilaku Hidup Bersih dan Sehat

\section{Tahap IV}

Pembagian Sikat Gigi dan

Pasta Gigi Gratis

Tujuannya:

Dijadikan sebagai motivasi

Tahap V

Evaluasi Kegiatan dan Tindak Lanjut

Tujuannya:

1. Mengevaluasi semua kegiatan yang dilakukan.

2. Melihat kendala-kendala yang dihadapi Jemaat Mitra.

3. Mempersiapkan tindak lanjut yang harus dilakukan. dalam kehidupan sehari-hari.

Partisipasi Mitra:

Mitra mempersiapkan lokasi, peserta, dan dokumen.

Tahap ini kegiatannya adalah

1. Penyuluhan Kesehatan tentang Perilaku Hidup Bersih dan Sehat

2. Mengajak Hidup Bersiha dan Sehat melalui Praktek Hidup Bersih dan Sehat

Partisipasi Mitra:

Mitra mempersiapkan lokasi, peserta, dan dokumen yang dibutuhkan
Tahap ini kegiatannya adalah

Pembagian Sikat Gigi dan Pasta Gigi kepada 184 Anak Sekolah Minggu

Partisipasi Mitra:

Mitra mempersiapkan tempat, peserta, dan dokumen yang dibutuhkan

Tahap ini, akan dilakukan evaluasi terhadap semua kegiatan yang dilakukan, melihat kendala-kendala yang dihadapi oleh mitra dan mempersiapkan tindak lanjut yang harus dilakukan. Kegiatan yang dilakukan adalah

a. Berdiskusi dengan mitra untuk melihat kendala dan progress terkait solusi yang dilakukan.

b. Menyiapkan tindak lanjut untuk mengatasi kendala demi keberlanjuta Pembudayaan Perilaku Hidup Bersih dan Sehat.

c. Menyiapkan laporan dan publikasi

Partisipasi Mitra:

Mitra menyiapkan lokasi, peserta, dan dokumen yang dibutuhkan 


\section{Hasil}

\section{Tahap Persiapan}

Program pengabdian kepada masyarakat yang dilakukan diawali dengan pembentukan tim yang terdiri dari dua orang dosen, yaitu: Resa Dandirwalu dan Desviana Maspaitella, dan dua belas mahasiswa, yaitu: Nining Gan, Yonaria Pattiapon, Vonda Leasa, Pingkan P. Alfons, Jems Porumau, Eveline L. Kastanja, Dennyela P. Siwabessy, Koce Tuatanasy, Melina Letelay, Rezky B. Tahalele, Yusuf R. Serpiela, dan Marsel Mangar. Tim mengidentifikasi Mitra yang dijadikan sebagai lokasi Pengabdian kepada Masyarakat, dan Tim menentukan Jemaat GPM Tihulale sebagai Mitra, kemudian, Tim melakukan koordinasi dengan Ketua Majelis Jemaat untuk mendapatkan persetujuan, dan akhirnya disetujui untuk menerima Tim melakukan kegiatan Pengabdian kepada Masyarakat.

Tanggal 07 Februari 2020, pukul 07.00 WIT, Tim menuju ke lokasi Mitra dengan menggunakan Roda Empat dan Kapal Ferry hingga tiba di Jemaat Mitra pada pukul 14.30 WIT, dan Tim melakukan Pengabdian kepada Masyarakat di Jemaat Mitra dari tanggal 07 Februari hingga tanggal 08 Maret 2020. Setelah melakukan observasi dan wawancara dengan Ketua Majelis Jemaat GPM Tihulale, maka disepakati bahwa persoalan utama yang sedang dihadapi adalah Pembudayaan Perilaku Hidup Bersih dan Sehat kepada Anak-Anak Sekolah Minggu, sebab selama ini mereka belum adanya pengetahuan dan ketrampilan yang memadai tentang Pembudayaan Perilaku Hidup Bersih dan Sehat dari Anak-Anak Sekolah Minggu. Karena itu, Tim bersepakat dengan Mitra untuk memberikan Penyuluhan dan Pelatihan kepada Anak-Anak Sekolah Minggu, yang berlangsung pada Hari Minggu, tanggal 16 Februari 2020, di Balai Pertemuan Negeri Tihulale.

\section{Tahap Pelaksanaan Pendampingan}

Tahap pelaksanaan dilakukan melalui penyuluhan dan ketrampilan ${ }^{11}$ dalam pendampingan perilaku hidup bersih dan sehat kepada Anak-anak Sekolah Minggu Jemaat Gereja Protestan Maluku (GPM) Tihulale Seram Barat Maluku.

\section{Kegiatan Penyuluhan}

Tim melakukan kegiatan penyuluhan tentang Pembudayaan Perilaku Hidup Bersih dan Sehat kepada Anak-Anak Sekolah Minggu, pada hari Minggu, tanggal 16 Februari 2020, pukul 12.00-14.00 WIT, di Balai Pertemuan Negeri Tihulale. Anak-Anak Sekolah Minggu yang terlibat sebanyak 184 Anak, dengan perincian: Anak Kecil 81 orang, Anak Tanggung 52 Anak, dan Anak Remaja 51. Kegiatan diawali dengan proses

11 Agni Rimba Mawan, Sri Endah Indriwati, and Suhadi, "Pengembangan Video Penyuluhan Perilaku Hidup Bersih Dan Sehat (PHBS) Bermuatan Nilai Karakter Terhadap Peningkatan Pengetahuan Masyarakat Dalam Menanggulangi Penyakit Diare," Jurnal Pendidikan 2, no. 7 (2017): 883-888. 
pre-test kepada 87 Anak, dengan cara Tim membagikan kuisener yang berisi 10 pertanyaan untuk dijawab oleh Anak-Anak Sekolah Minggu, dengan tujuan mengukur pemahaman awal dari mereka tentang Pembudayaan Perilaku Hidup Bersih dan Sehat. Hasilnya adalah terdapat 65 persen Anak-Anak Sekolah Minggu yang pemahaman masih cukup rendah tentang Pembudayaan Perilaku Hidup Bersih dan Sehat.

Materi penyuluhan diawali dengan contoh-contoh yang dialami apabila tubuh dan lingkungan tidak bersih, di antaranya adalah sakit diare yang dapat membunuh manusia, khususnya pada anak-anak, maka ditampilkan data dari hasil penelitian dari Organisasi Kesehatan Dunia, yang menunjukan bahwa terdapat 100.000 anak Indonesia meninggal dunia akibat penyakit diare yang diderita, dan data dari Departemen Kesehatan RI, yang memperlihatkan terdapat 300 orang yang terjangkit penyakit diare. Dilanjutkan dengan memberikan pengertian dasar tentang Perilaku Hidup Bersih dan Sehat; pentingnya Perilaku Hidup Bersih dan Sehat; dan bentuk-bentuk Perilaku Hidup Bersih dan Sehat, seperti: mencuci tangan dengan air bersih yang mengalir dan memakai sabun, jajan di warung sekolah yang sehat, membuang sampah pada tempatnya, mengikuti kegiatan olahraga di sekolah dan kegiatan-kegiatan yang berupa aktivitas fisik, rajin menggosok gigi, dan menggunakan jamban sehat.

Metode yang dipergunakan dalam menyampaikan materi adalah ceramah dan Tanya jawab, supaya mudah Anak-Anak Sekolah Minggu bisa mengikuti materi dengan baik dan dapat mengerti, sehingga berpengaruh pada peningkatan pemahaman dan terjadinya perubahan perilaku mereka terkait Hidup Bersih dan Sehat. Materi tertulis disajikan menggunakan microsoft powerpoint yang dimunculkan melalui LCD Projector InFocus, sehingga memudahkan Anak-Anak Sekolah Minggu mengikutinya; selain itu, ditampilkan video yang berdurasi 10 menit tentang model mencuci tangan dan menyikat gigi yang baik dan benar.
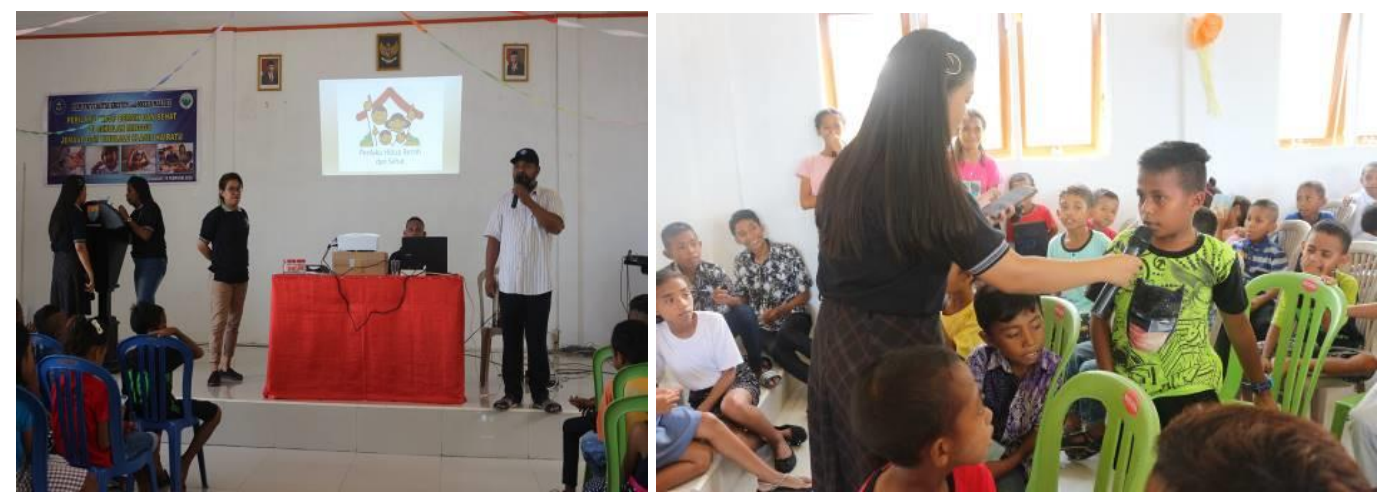

Gambar 1. Sessi Penyuluhan (kiri) dan Proses Tanya Jawab dalam Pembudayaan Perilaku Hidup Bersih dan Sehat Anak Sekolah Minggu (kanan)

Selama proses penyuluhan, terlihat Anak-Anak Sekolah Minggu sangat senang dan memiliki antusias yang tinggi untuk mengikuti dari awal hingga akhir materi yang disajikan, maka pengaruhnya adalah terciptanya dinamika di antara Anak-Anak Sekolah Minggu melalui pertanyaan-pertanyaan yang diberikan kepada Penyuluh dan jawaban 
yang disampaikan berdasarkan pertanyaan-pertanyaan dari Penyuluh kepada AnakAnak Sekolah Minggu.

Kegiatan Penyuluhan diakhiri dengan kegiatan post-test kepada 87 Anak yang melakukan proses pre-test, untuk mengukur ketercapaian pengetahuan mereka sesudah materi disampaikan, dan hasilnya adalah terdapat 85 persen Anak-Anak Sekolah Minggu yang mengalami peningkatan pemahaman tentang Pembudayaan Perilaku Hidup Bersih dan Sehat. Peningkatan pemahaman tersebut tampak pada Ibadah Sekolah Minggu yang berlangsung setiap hari Minggu, di Gedung Gereja Beth Eden, Jemaat GPM Tihulale, dan kehidupan sehari-hari mereka di rumah.

\section{Kegiatan Pelatihan}

Sesudah kegiatan penyuluhan tentang Pembudayaan Perilaku Hidup Bersih dan Sehat, maka dilanjutkan dengan proses pelatihan cara mencuci tangan dan menyikat gigi yang baik dan benar. Pelatihan tersebut berlangsung pada hari Minggu, tanggal 16 Februari 2020, pukul 14.00-15.00 WIT, di Balai Pertemuan Negeri Tihulale, dan AnakAnak Sekolah Minggu yang terlibat sebanyak 184 Anak, dengan perincian: Anak Kecil 81 orang, Anak Tanggung 52 Anak, dan Anak Remaja 51.

Kegiatan pelatihan diawali dengan proses pre-test kepada 87 Anak, dengan cara Tim membagikan kuisener yang berisi 10 pertanyaan untuk dijawab oleh Anak-Anak Sekolah Minggu, dengan tujuan mengukur pengetahuan mereka tentang cara mencuci tangan dan menyikat gigi yang baik dan benar. Hasilnya adalah terdapat 55 persen Anak-Anak Sekolah Minggu yang pemahaman masih cukup rendah tentang cara mencuci tangan dan menyikat gigi yang baik dan benar.

Pelatihan cara mencuci tangan dan menyikat gigi diawali dengan pemutaran video yang berdurasi 10 menit, sambil Tim memperagakan sesuai dengan video tersebut. Sesudah itu, Tim memberikan kesempatan kepada Anak-Anak Sekolah Minggu untuk mengikuti gerakan sesuai dengan gerakan yang terdapat dalam video yang sedang diputarkan. Video tersebut diputarkan sebanyak 3 kali, supaya mereka menjadi terampil untuk melakukannya.
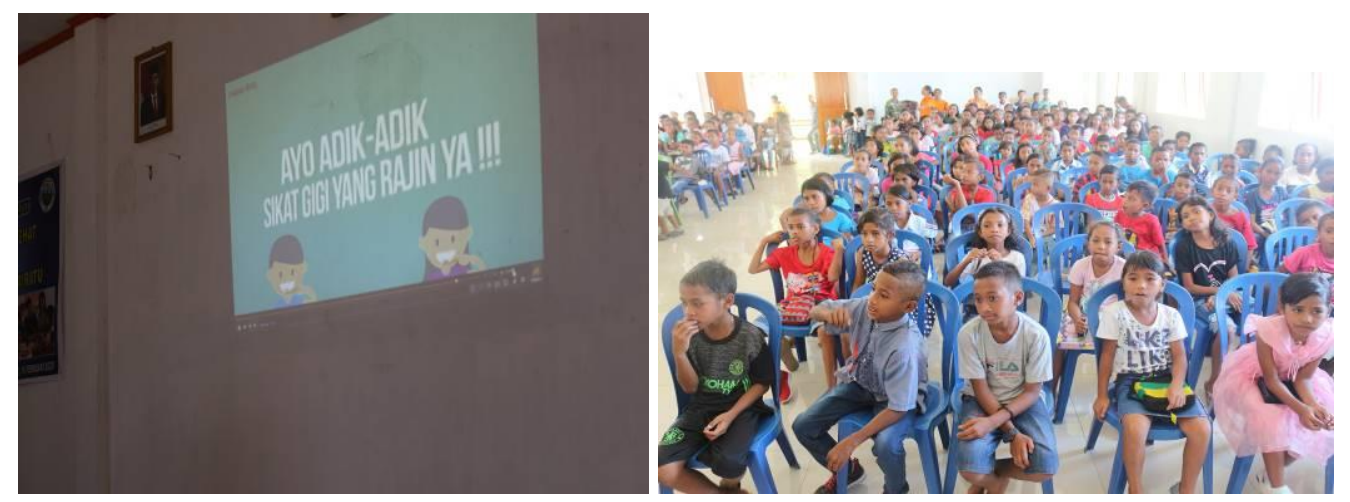

Gambar 2. Pemutaran Video (kiri) dan gambar Anak Sekolah Minggu sangat antusias dalam mengikuti pendampingan 
Selanjutnya, Tim membagi Anak-Anak sesuai dengan Jenjang untuk memperagakan cara mencuci tangan dan menyikat gigi di hadapan Anak-Anak Sekolah Minggu yang lainnya. Setiap Jenjang terdiri dari 4-5 anak untuk memperagakannya. Tampak bahwa mereka cenderung bisa memperagakan cara mencuci tangan dan menyikat gigi dengan baik dan benar sesuai dengan video yang diputarkan. Selama peragaan dilakukan oleh setiap Jenjang, terlihat adanya partisipasi dan antusias yang tinggi dari mereka. Diakhir kegiatan Penyuluhan dan Pelatihan, Tim memberikan bantuan kepada 317 Anak-Anak Sekolah Minggu yang mengikuti kegiatan tersebut, sebagai motivasi sekaligus menggantikan sikat gigi mereka yang lama, agar terciptanya hidup bersih dan sehat.
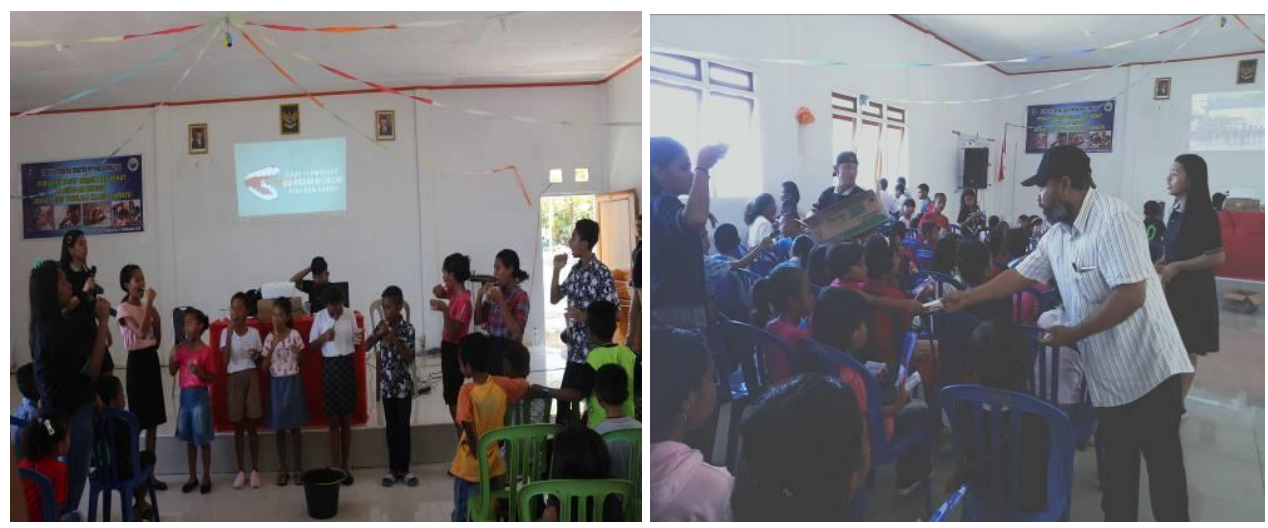

Gambar 3. Praktek Cara Menyikat Gigi Yang Baik dan Benar (kiri) dan Pembagian Sikat Gigi dan Pasta Gigi (kanan)

Kegiatan Pelatihan diakhiri dengan kegiatan post-test kepada 87 Anak yang melakukan proses pre-test, untuk mengukur ketercapaian pengetahuan mereka sesudah materi disampaikan, dan hasilnya adalah terdapat 80 persen Anak-Anak Sekolah Minggu yang mengalami peningkatan pemahaman tentang cara mencuci tangan dan menyikat gigi yang baik dan benar.

\section{Tahap Evaluasi dan Tindak Lanjut}

Kegiatan Penyuluhan dan Pelatihan tentang Pembudayaan Perilaku Hidup Bersih dan Sehat dikatakan berhasil, karena berdasarkan evaluasi antara Tim dengan Mitra, mereka memandang bahwa Penyuluhan dan Pelatihan yang diikuti memberikan manfaat yang tinggi dan memuaskan, sehingga tindak lanjutnya adalah Tim dan Mitra terus membangun kerjasama dan kemunikasi yang intens, sehingga Pembudayaan Perilaku Hidup Bersih dan Sehat terus dihidupkan dalam kehidupan sehari-hari, agar terciptalah kualitas hidup Mitra, khususnya Anaka-Anak Sekolah Minggu. 


\section{Diskusi}

Bertolak pada hasil pendampingan Perilaku Hidup Bersih dan Sehat tergambar bahwa perubahan pemahaman dan peningkatan ketrampilan Anak-Anak Sekolah Minggu Jemaat GPM Tihulale tentang Pembudayaan Perilaku Hidup Bersih dan Sehat, sangat dipengaruhi oleh pengetahuan mereka. Realitas inilah yang digambarkan oleh Gracia, dkk, bahwa pengetahuan menjadi salah satu faktor pembentukan Perilaku Hidup Bersih dan Sehat, sehingga mempengaruhi status kesehatan setiap individu, ${ }^{12}$ sehingga menurut Husni Abdul Gani, dkk, harus dilaksanakan secara sistematis dan terkoordinir, sebagai bentuk pengalaman belajar, untuk meningkatkan pengetahuan, sikap dan perilaku agar dapat menerapkan cara-cara hidup sehat dalam rangka menjaga, memelihara, dan meningkatkan kesehatan. ${ }^{13}$ Dengan demikian, tujuan dari Peraturan Menteri Kesehatan Republik Indonesia Nomor: 226/MENKES/PER/XI/2011, tentang Perilaku Hidup Bersih dan Sehat di Seluruh Indonesia, yang dimulai dari tahap pengkajian, perencanaan, pelaksanaan, pemantauan dan penilaian, dapat tercapai. ${ }^{14}$

Materi yang diberikan pada Kegiatan Penyuluhan adalah: pengertian dasar tentang Perilaku Hidup Bersih dan Sehat; pentingnya Perilaku Hidup Bersih dan Sehat; dan bentuk-bentuk Perilaku Hidup Bersih dan Sehat, seperti: mencuci tangan dengan air bersih yang mengalir dan memakai sabun, jajan di warung sekolah yang sehat, membuang sampah pada tempatnya, mengikuti kegiatan olahraga di sekolah dan kegiatan-kegiatan yang berupa aktivitas fisik, rajin menggosok gigi, dan menggunakan jamban sehat. Berbagai materi tersebut untuk membangun cakrawala berpikir AnakAnak Sekolah Minggu, supaya berpengaruh pada perilaku kesehatan yang dilakukan setiap hari, agar setiap individu dapat memelihara dan meningkatkan kesehatan, ${ }^{15}$ sehingga terciptalah tubuh yang sehat untuk melaksanakan seluruh aktivitas yang dilakukan. ${ }^{16}$ Dengan kata lain hidup menjadi baik sangat berhubungan erat dengan kesehatan. ${ }^{17}$

\footnotetext{
12 Gracia V. Souisa, Ivy V. Lawalata, Samuel Titaley, "Peningkatan Perilaku Hidup Bersih Dan Sehat (PHBS) Pada Pendidik Dan Peserta Didik Di Kecamatan Leihitu Barat Kabupaten Maluku Tengah."

${ }^{13}$ Gani et al., "Perilaku Hidup Bersih Dan Sehat (PHBS) Pada Tatanan Rumah Tangga Masyarakat Using (Studi Kualitatif Di Desa Kemiren, Kecamatan Glagah, Kabupaten Banyuwangi) A Qualitative Study in Kemiren Village, Glagah Sub District, Banyuwangi Regency."

14 Tentama, "Penerapan Perilaku Hidup Bersih Dan Sehat (PHBS) Demi Kesejahteraan Masyarakat Kecamatan Tuntang Kabupaten Semarang Jawa Tengah.”

15 Susanti and Kholisoh, "Konstruksi Makna Kualitas Hidup Sehat (Studi Fenomenologi Pada Anggota Komunitas Herbalife Klub Sehat Ersanddi Jakarta)."

${ }_{16}$ Muniatin, Busri, "Pengenalan Pola Hidup Sehat Melalui Media Langsung Pada Anak Usia 4-5 Tahun RA AL-Hidayah."

${ }^{17}$ Sufa, Christantyawati, dan Jusnita, "Tren Gaya Hidup Sehat Dan Saluran Komunikasi Pelaku Pola Makan Food Combining."
} 


\section{Kesimpulan}

Pendampingan tentang pembudayaan perilaku hidup bersih dan sehat bagi anakanak Sekolah Minggu yang dilakukan secara sistematis dan terkoordinir dengan baik akan mampu memberikan perubahan kepada anak-anak Sekolah Minggu tentang perilaku hidup bersih dan sehat. Perubahan ini terlihat dari: pertama, terjadi peningkatan pengetahuan tentang pembudayaan perilaku hidup bersih dan sehat; dan kedua, anak-anak Sekolah Minggu memiliki ketrampilan yang memadai tentang cuci tangan dan sikat gigi yang baik dan benar, agar mereka dapat mengaplikasikannya dalam kehidupan sehari-hari.

\section{Pengakuan}

Terima kasih yang sebesar-besarnya Tim sampaikan kepada Lembaga Pengabdian Masyarakat Universitas Kristen Indonesia Maluku yang boleh memberikan anggaran, sehingga kegiatan Pengabdian boleh terlaksana dengan kelompok mitra, yaitu Jemaat GPM Tihulale, khususnya anak-anak Sekolah Minggu, dan mitra yang bersedia menyiapkan tempat dan peserta, sehingga kegiatan pengabdian boleh berlangsung dengan baik.

\section{Daftar Referensi}

Aeni, Qurrotul, Fiera Beniarti, and Bambang Edy Warsito. "Pengaruh Pendidikan Kesehatan Dengan Metode Pemutaran Video Tentang PHBS Cuci Tangan Terhadap Pengetahuan Dan Sikap." Jurnal Keperawatan 7, no. 2 (2015): 1-5. http://journal.stikeskendal.ac.id/index.php/Keperawatan/article/view/18.

Chandra, Akhmad Fauzan, and M Febriza Aquarista. "Hubungan Antara Pengetahuan Dan Sikap Dengan Perilaku Hidup Bersih Dan Sehat (Phbs) Pada Siswa Sekolah Dasar (Sd) Di Kecamatan Cerbon Tahun 2016." Jurnal Kesmas (Kesehatan Masyarakat) Khatulistiwa 4, no. 3 (2017): 201.

Gani, Husni Abdul, Erdi Istiaji, Prita Eka Pratiwi, Bagian Promosi Kesehatan, Ilmu Perilaku, and Fakultas Kesehatan. "Perilaku Hidup Bersih Dan Sehat (Phbs) Pada Tatanan Rumah Tangga Masyarakat Using (Studi Kualitatif Di Desa Kemiren, Kecamatan Glagah, Kabupaten Banyuwangi) A Qualitative Study in Kemiren Village, Glagah Sub District, Banyuwangi Regency." Jurnal IKESMA 11, no. 1 (2015): 26-35.

Gracia V. Souisa, Ivy V. Lawalata, Samuel Titaley, Bellytra Talarima. "Peningkatan Perilaku Hidup Bersih Dan Sehat (PHBS) Pada Pendidik Dan Peserta Didik Di Kecamatan Leihitu Barat Kabupaten Maluku Tengah." Pengabdian Kepada Masyarakat 24, no. 3 (2018): 747-754. 
Jemaat GPM Tihulale (tidak dipublikasikan). Renstra Jemaat GPM Tihulale Tahun 20152020.

Mawan, Agni Rimba, Sri Endah Indriwati, and Suhadi. "Pengembangan Video Penyuluhan Perilaku Hidup Bersih Dan Sehat (PHBS) Bermuatan Nilai Karakter Terhadap Peningkatan Pengetahuan Masyarakat Dalam Menanggulangi Penyakit Diare." Jurnal Pendidikan 2, no. 7 (2017): 883-888.

Muniatin, Busri, Halida. "Pengenalan Pola Hidup Sehat Melalui Media Langsung Pada Anak Usia 4-5 Tahun RA AL-Hidayah." Journal of Chemical Information and Modeling 53, no. 9 (2013): 1689-1699.

Obella, Zaraz, and Nur Adliyani. "Pengaruh Perilaku Individu Terhadap Hidup Sehat The Effect of Human Behavior for Healthy Life." Majority 4, no. 7 (2015): 109-114.

Sufa, Siska Armawati, Nevrettia Christantyawati, and Raden Ayu Erni Jusnita. "Tren Gaya Hidup Sehat Dan Saluran Komunikasi Pelaku Pola Makan Food Combining." Jurnal Komunikasi Profesional 1, no. 2 (2017): 105-120.

Susanti, Endang, and Nur Kholisoh. "Konstruksi Makna Kualitas Hidup Sehat (Studi Fenomenologi Pada Anggota Komunitas Herbalife Klub Sehat Ersanddi Jakarta).” LUGAS Jurnal Komunikasi 2, no. 1 (2018): 1-12.

Tentama, Fatwa. "Penerapan Perilaku Hidup Bersih Dan Sehat (Phbs) Demi Kesejahteraan Masyarakat Kecamatan Tuntang Kabupaten Semarang Jawa Tengah." Jurnal Pemberdayaan: Publikasi Hasil Pengabdian Kepada Masyarakat 1, no. 1 (2018): 13. 